\title{
TERMINATION OF TRUSTS IN PENNSYLVANIA- SOME CURRENT TRENDS
}

\section{MTNTURN T. WRTGHT, III}

In recent years beneficiaries of Pennsylvania trusts have increasingly sought to terminate the trusts. Most of these attempts have begun and ended in the Orphans' Courts. In general, these courts have responded with a flexible approach which leans heavily on what might be called equitable considerations. ${ }^{1}$ At the same time the courts are making certain that it is they, rather than the beneficiaries, who make the decisions.

This article will deal with the three grounds which resourceful beneficiaries have most often advanced for the termination of trusts: (1) the consent of all the parties in interest; (2) the failure of the purpose for which the trust was created; and (3) mistake as to the terms or effect of the trust. ${ }^{2}$

\section{Termination Upon Consent of Parties in Interest}

If the settlor of an inter vivos trust is living and joins with all persons beneficially interested in the trust in requesting termination, the trust will be terminated even though the purpose of its creation has not been fulfilled. In Bozvers' Trust Estate, ${ }^{3}$ the settlor of an inter vivos spendthrift trust joined with all persons beneficially interested in the trust in requesting its termination. The Court ordered that it be terminated, even though the special purpose of the trust had not been fulfilled. The trust had been created by a woman in contemplation of her marriage, the income to be paid to herself for her sole and separate use for life and on her death to her son, who

† Lecturer, University of Pennsylvania Law School. B.A., Yale University, 1949, LL.B., Úniversity of Pennsylvania, 1952. Member, Pennsylvania Bar.

1 The courts do not deal with the problem of termination entirely unaided by legislation. Section 2(a) of the Estates Act of 1947 is particularly relevant.

(a) Failure of original purpose. The court having jurisdiction of a trust . . regardless of any spendthrift or similar provision therein, in its discretion may terminate such trust in whole or in part... provided the court after hearing is satisfied that the original purpose of the conveyor cannot be carried out or is impractical of fulfillment and that the termination $\because$. more nearly approximates the intention of the conveyor, and notice is given to all parties in interest ... .

Pa. Stat. Ann. tit. 20, §301.2(a) (Supp. 1966).

2 Other methods for ending a trust include revocation, the expiration of the term and impossibility or illegality of purpose. See 3 Scorr, Trusts, $\S \S 330,334,335$ (2d ed. 1956, Supp. 1965).

3346 Pa. 85, 29 A.2d 519 (1943). 
would receive the principal partly at age twenty-five and partly at age thirty. The son reached the age of thirty-five, acquiring what all conceded to be an indefeasible interest, and assigned his interest to the life tenant. Her petition to terminate the trust was granted. The Court expressly adopted the rule of section 338 of the Restatement of Trusts, that if all parties in interest agree, a trust may be terminated notwithstanding that its purpose has not been accomplished. ${ }^{4}$ The rule was reaffirmed in Schellentrager $v$. Tradesmens National Bank \& Trust $\mathrm{Co}^{5}$

Prior to Bowers there was a line of older cases in Pennsylvania standing for the proposition that where a settlor creates a spendthrift trust for himself he may not thereafter terminate it. ${ }^{6}$ These decisions would seem to have been effectively overruled by Bowers and Schellentrager. However, a recent. decision by the Orphans' Court of Philadelphia indicates that the reasoning of the pre-Bowers cases still has considerable vitality. In Palermo Trust, ${ }^{7}$ a young woman, crippled in a railroad accident, had been prevailed upon to create an irrevocable spendthrift trust of the proceeds of her accident claim. Under it, the trustee was to pay her the income and such amounts of principal as he thought necessary for her support. The remainder was payable to her estate. A year later she changed her mind and sought to terminate the trust, claiming a right to do so under Bowers; the trustee joined in her petition, which was opposed only by a "trustee ad litem" appointed by the Court. 8 The Court refused to terminate, relying on the early Pennsylvania cases for the proposition that one who creates a spendthrift trust for himself constitutes himself a "ward of the court," ${ }^{8}$ and cannot terminate the trust without the Court's approval.

The court sought to distinguish Bowers by pointing out that there the "trust had run its course" 10 while here the settlor, a paraplegic absolutely dependent on others, was under an "incapacity"

4 Restatement (Second), Trusts, §338 (1959). See also id. §339.

$5370 \mathrm{~Pa}$. 501, 88 A.2d 773 (1952). Lower court cases applying the Bowers rule include, Chase Trust, Pa. 7 D. \& C.2d 519 (Philadelphia Orphans' Ct. 1956); Goodell's Estate, 53 Pa. D. \& C. 13 (Philadelphia Orphans' Ct. 1945) ; Ammon's Trust Estate, 52 Pa. D. \& C. 509 (Berks County Orphans' Ct. 1944).

${ }^{6}$ Rehr v. Fidelity-Philadelphia Trust Co., $310 \mathrm{~Pa} .301,165$ Atl. 380 (1933); King v. York Trust Co., $278 \mathrm{~Pa}$. 141, 122 Atl. 227 (1923); Willard v. Integrity Trust Co., 273 Pa. 24, 116 At1. 513 (1922) ; Fry v. Mercantile Trust Co., 207 Pa. 640, 57 Atl. 43 (1904); Potter v. Fidelity Ins. Trust \& Safe Deposit Co. (No. 1), 199 Pa. 360, 49 Atl. 85 (1901); Rynd v. Baker, 193 Pa. 486, 44 Atl. 551 (1899); Reidy v. Small; 154 Pa. 505, 26 At1. 602 (1893); Ashurst's Appeal, 77 Pa. 464 (1875).

715 Fid. Rep. 74 (Philadelphia Orphans' Ct. 1963).

${ }^{8}$ It does not appear who the trustee ad litem represented, since no one but the settlor had an interest in the trust.

$\theta 15$ Fid. Rep. at 83.

10 Id. at 81 . 
that subjected her to the court's control. ${ }^{11}$ It is difficult to see how this decision comports with Bowers, especially in light of the Supreme Court's statement that to deny the settlor the right to terminate a trust in which he holds all the interests "in effect prevents a person from doing as he pleases with his own property." 12 Nevertheless, the court in Palermo asserted its power to limit this right. ${ }^{13}$

If the creator of the trust is dead, the beneficiaries may terminate it only if its purposes have been fulfilled. ${ }^{14}$ Implicit in this rule is the view that a "material purpose" is not deduced merely from the existence of the trust. A concrete expression of this view is Stafford's Estate, ${ }^{15}$ where the remainderman acquired the life estate, and the court terminated the trust on finding that its purpose had merely been to protect the corpus during the pendency of the life estate. Another example is Wood's Estate, ${ }^{16}$ where the life tenant had a general power to appoint the remainder, and the court terminated the trust at her request on the ground that the trust did not support remainders and was "passive." 17

11 It is difficult to read Bowers as the court did in Palermo. In Bowers the Supreme Court adopted the rule of section 338 of the Restatement of Trusts, allowing all interested parties to terminate a trust "although the purpose of the trust has not been accomplished." Palermo read Bowers as "not expressly over-ruling" the earlier Pennsylvania decisions, 15 Fid. Rep. at 81, but Bozvers surely disapproved of these decisions by describing them as "not .. in accord with [the Restatement's] pronouncements." $346 \mathrm{~Pa}$. at 88, 29 A.2d at 520. Palermo also relied on the Restatement's exception in section 339 that a person under an "incapacity" cannot join in a termination of a trust, and concluded that this applied to a crippled settlor. However, "incapacity" in section 339 of the Restatement clearly means legal incapacity and expressly does not include a person who manages his affairs unwisely.

$12346 \mathrm{~Pa}$. at $89,29 \mathrm{~A} .2 \mathrm{~d}$ at 521 .

13 Palermo has some company. In Collins v. Provident Trust Co. of Phila., 83 Pa. D. \& C. 459 (Montgomery County C.P. 1952), a spendthrift trust was held not terminable because all parties in interest were not represented. But the court, in a brief final paragraph, also said that solely because the trust was a spendthrift trust, it could not be revoked in any event, citing one of the pre-Bozvers cases.

14 See generally 3 ScoTr, TRUSTS $\$ 337$ (2d ed. 1956), where the rule is compared - to the rule in England that a trust may be terminated upon the consent of all the beneficiaries, whether or not there is a material purpose still to be served by its continuance. Some early Pennsylvania cases suggest the English rule. See Culbertson's Appeal, $76 \mathrm{~Pa} .145$ (1874), where the court granted termination declaring that if all interested parties consent, a trust may be terminated even though its purposes have not been accomplished. However, the court also stated that since the children were of age, the purpose of the trust had been completed. In Yarnall's Appeal, 70 $\mathrm{Pa} .335$ (1872), termination of a spendthrift trust was granted on a finding that the life tenant had a fee simple, and nothing was said about the spendthrift clause or any other "purpose" of the trust.

$15258 \mathrm{~Pa} .595,102$ At1. 222 (1917).

16261 Pa. 480, 104 Atl. 673 (1918).

17 More recent examples of the rule include Holmes Estate, $66 \mathrm{~Pa}$. D. \& C. 612 (Delaware County Orphans' Ct. 1949) and McClain Estate, 69 Pa. D. \& C. 29 (Fulton County Orphans' Ct. 1949). In the former, the court terminated a sole and separate use trust where the beneficiary was not married nor in contemplation of marriage at the time the trust was created. In the latter, a trust was terminated on the petition of the beneficiaries on a finding that the testator's purpose was merely to preserve the corpus for the remaindermen, and not to protect the widow-life tenant to whom he had given outright a substantial portion of his estate. 
The principal example of a material purpose is a spendthrift trust. Except for one or two of the earliest cases, ${ }^{18}$ it has been held uniformly in Pennsylvania that a testamentary spendthrift trust may not be terminated at the request of all the beneficiaries, although the rationale has varied widely from case to case. ${ }^{19}$ A second recognized "purpose" is found in charitable trusts, which will not be terminated at the request of the charity. ${ }^{20}$ A third example is a discretionary or support trust. $^{21}$ Other examples include trusts for persons under a disability. ${ }^{22}$

Most discussions of the subject give the impression that a trust will be readily terminated if it does not fit into one of these established

18 E.g., Yarnall's Appeal, 70 Pa. 335 (1872).

19 The leading case is Bosler Estate, $378 \mathrm{~Pa} .333,107 \mathrm{~A} .2 \mathrm{~d} 443$ (1954), which stressed the testator's right to dispose of his property as he wished. In Borsch Estate, $362 \mathrm{~Pa}$. 581, 67 A.2d 119 (1949), the Supreme Court went so far as to hold a spendthrift clause a "property right." In Grote Trust, 390 Pa. 261, 135 A.2d 383 (1957), the court cited Bosler and Borsch with approval.

The long line of earlier cases includes: Heyl Estate, $352 \mathrm{~Pa} .407,43$ A.2d 130 (1945), Harrison's Estate, $322 \mathrm{~Pa} .532,185$ Atl. 766 (1936) (no termination of trust with remainder to charity under Act of April 14, 1931, P.L. 29); Moser's Estate, $270 \mathrm{~Pa} .217,113$ Atl. 199 (1921) (no merger of spendthrift life estate and remainder); Fox's Estate, 264 Pa. 478, 107 Atl. 863 (1919) (no termination though spendthrift life tenant and trustee same person); Simonin's Estate, $260 \mathrm{~Pa} .395,103$ Atl. 927 (1918) (semble); Moore's Estate, 198 Pa. 611, 48 Atl. 884 (1901) (no merger of spendthrift life estate and remainder). See also Close Estate, $83 \mathrm{~Pa}$. D. \& C. 136 (Philadelphia Orphans' Ct. 1953). There are at least three recent cases which have permitted the termination of testamentary spendthrift trusts contrary to the general rule. One is Kelby Estate, 80 Pa. D. \& C. 1 (Philadelphia Orphans' Ct. 1952), where the court admittedly was extending the rule of Bozvers, involving inter vivos trusts, to testamentary trusts. Being somewhat unsure of this, however, the court allowed termination on the second and independent ground of failure of purpose. (The principal had shrunk.) See Honeywell Estate, 70 Pa. D. \& C. 472 (Montgomery County Orphans' Ct. 1950), which is quite similar.

In Wormser Estate, $85 \mathrm{~Pa}$. D. \& C. 526 (Lackawanna County Orphans' Ct. 1953), the court held that the life tenants had a fee, and granted termination, saying the spendthrift clause was immaterial. It cited cases holding that the owner of a life estate with a general power of appointment has a fee, even though a spendthrift clause exists. The cases cited were not termination cases, but all involved the question of whether a subsequent beneficiary is bound by the life tenant's acquiescence or other conduct.

20 Baughman's Estate, $281 \mathrm{~Pa} .23,126$ Atl. 58 (1924), in which the court said that testator had created a trust to keep the beneficiary (a church) from consuming the corpus; cf. Biehl Estate, 35 D. \& C. 148 (Philadelphia Orphans' Ct. 1965), where funds bequeathed to a corporate trustee in trust for four charities were awarded directly to the charities because the named trustee had no legal power to act as such.

21 Spring's Estate, $216 \mathrm{~Pa}$. 529, 66 Atl. 110 (1907). See BrEGy, InTestate, WILLS AND ESTATES Acrs of 1947 at 5157 (1949). This is not considered a material purpose in England. See 3 Scotr, TruSTS \$337.4 (2d ed. 1956, Supp. 1965).

22 Several cases have involved trusts created for the benefit of a beneficiary who was under a disability, such as minority, incompetency, coverture or drunkenness, which subsequently ceased. See 3 Scorr, Trusts $\$ 337.5$ (2d ed. 1956, Supp. 1965). In Simon's Estate, 34 Pa. D. \& C. 475 (Philadelphia Orphans' Ct. 1939) and in Dodson v. Ball, $68 \mathrm{~Pa}$. 492 (1869), a woman was allowed to terminate a trust for her benefit, following divorce. However, in Moore's Estate, $35 \mathrm{~Pa}$. D. \& C. 694 . (Philadelphia Orphans' Ct. 1939), the court refused to hold that a divorce terminated a trust created for the benefit of a grandson during his marriage. See also King v. York Trust Co., $278 \mathrm{~Pa}$. 141, 122 Atl. 227 (1923), where a spendthrift trust was created by a man fearing incompetency, and the court refused to terminate it many years later at the request of the settlor and some of the other beneficiaries. See Willard v. Integrity Trust Co., $273 \mathrm{~Pa}$. 24, 116 Atl. 513 (1922) for a trust created by a drunkard. 
categories of "material purpose." ${ }^{23}$ As noted, the rule itself is based on an assumption that the necessary purpose is not derived merely from the creation of the trust, and Pennsylvania decisions such as Stafford and Wood support this conclusion. However, there are a number of cases refusing to terminate trusts, involving neither spendthrift clauses nor support. This is done on the broad ground, variously stated, that the testator intended a trustee to manage the property for the beneficiary and that the intent must be carried out. This attitude was indistinctly suggested by the Supreme Court in Grazier's Estate, ${ }^{24}$ and in Slater Estate. ${ }^{25}$ It was made the basis of the decision in Cannistra Estate, ${ }^{26}$ where termination at the request of the beneficiaries was refused because there was an ultimate purpose to be served in continuing the trust. This purpose was stated to be merely that the testator intended to create an active trust and his intention would be carried out. ${ }^{27}$

A 1962 decision of the Philadelphia Orphans' Court illustrates and emphasizes this attitude and suggests that in general all trusts have a purpose to be carried out. Matthews Trust ${ }^{28}$ involved an attempted termination of a spendthrift trust by a release of the life estate in favor of the remainderman under section $3(a)$ of the Estates Act of $1947 .^{29}$ It is significant that in his decision Judge LeFever said very little about the spendthrift clause as creating a

23 In Bregy, Intestate, WIILS AND Estates Acts of 1947 (1949), the author states that aside from spendthrift and support trusts

special purposes are rare. The mere fact that the trust is by its terms supposed to last until the life tenant's death does not constitute a special purpose. Nor does the fact that the trust was supposed to last until the income beneficiary reached a certain age.

Id. at 5157. He refers to the cases holding that a trust to pay income to a person until he reaches a certain age, and then to pay him the principal, is an absolute gift. Decker Estate, 353 Pa. 509, 46 A.2d 218 (1946); Allen Estate, 347 Pa. 364, 32 A.2d 301 (1943); Zamichielli Estate, 81 Pa. D. \& C. 288 (Philadelphia Orphans' Ct. 1952). A gift over upon the death of the beneficiary before reaching the stated age prevents this result. Africa Estate, $359 \mathrm{~Pa} .567,59 \mathrm{~A} .2 \mathrm{~d} 925$ (1948). This is the rule in England, and apparently Pennsylvania is the only American state that follows it. See 3 Scotr, TRUSTS $\$ 337.3$ (2d ed. 1956, Supp. 1965).

24301 Pa. 422, 153 Atl. 390 (1930).

25316 Pa. 56, 173 Atl. 399 (1934).

26384 Pa. 605, 121 A.2d 157 (1956).

27 These cases borrow heavily from the so-called "active trust" cases of many years ago which generally dealt with whether a purported gift in trust created an "active trust" which would be sustained, or whether it was a "passive trust" executed by the Statute of Uses. See, e.g., Knight's Estate, 235 Pa. 149, 83 Atl. 709 (1912) (sole and separate use trust for daughter with general testamentary power of appointment, held active trust which she could not terminate) ; Shower's Estate, $211 \mathrm{~Pa} .297$, 60 Atl. 789 (1905) (trust to pay income to children, silent as to remainder, held active) ; Earp's Appeal, 75 Pa. 119 (1874) (trust to pay income to testator's children, with general testamentary power of appointment and gift in default of appointment, held active trust and sustained over children's efforts to extinguish it).

2812 Fid. Rep. 653 (Philadelphia Orphans' Ct. 1962).

29 PA. Stat. ANN. tit. 20, §301.3(a) (Supp. 1967). 
special purpose, but more broadly stated that to construe section 3 of the Estates Act to permit the release
.. would open the door to the termination of all trusts, spendthrift or not . . . where the life tenant and remainder- men are named and interests are vested. In such cases the agreeing parties, by whimsy or caprice, could circumvent the carefully considered and well-laid plan of testator or settlor to dispose of his property. ${ }^{30}$

Obviously for a trust to be terminated by the consent of the beneficiaries, all persons with interests in the trust must join. Many of the cases in this area involve the question of whether those consenting to the termination in fact hold all the beneficial interests in the trust. $^{31}$ Often the answer hinges on whether the gift of the remainder is phrased in such a way that under traditional rules of property the life tenant has a fee simple. ${ }^{32}$

Where, as is often the case, there are beneficial interests in an indefinite group such as "issue," some of whom may be minors or

3012 Fid. Rep. at 658. See also White Estate, $25 \mathrm{~Pa}$. D. \& C.2d 606 (Philadelphia Orphans' Ct. 1961), where the same court refused a petition to terminate, relying principally on the old doctrine of active trusts exemplified by Earp's Appeal, $75 \mathrm{~Pa}$. 119 (1874).

31 In a number of cases it was unquestionable that at least one interested party had not joined. Kamerly Estate, 348 Pa. 225, 35 A.2d 258 (1944); Donnan's Trust Estate, 339 Pa. 43, 13 A.2d 55 (1940); Gill's Estate, 293 Pa. 199, 142 Atl. 207 (1928); Jones' Trust Estate, $284 \mathrm{~Pa}$. 91, 130 At1. 314 (1925). See also Africa Estate, 359 Pa. 567, 59 A.2d 925 (1948) ; King v. York Trust Co., 278 Pa. 141, 122 Atl. 227 (1923); Lieberman v. Fabricant, 59 Pa. D. \& C. 443 (Philadelphia C.P. 1946).

32 Remainder to the "heirs" of the life tenant may give him a fee. See, e.g., Thorne's Estate, $344 \mathrm{~Pa}$. 503, 25 A.2d 511 (1942). But see Grazier's Estate, $301 \mathrm{~Pa}$. 422,153 Atl. 390 (1930). See 3 ScoTT, TRUSTs $\$ 340$ (2d ed. 1956), which suggests a difference based on whether the life tenant is the settlor, and on whether the Rule in Shelley's Case applies. Where the remainder is to such persons as the life tenant appoints by will, with a gift in default of appointment to his "heirs" or the equivalent, the life tenant has been held to have a fee and may terminate the trust. Mogridge's Estate, $342 \mathrm{~Pa}$. 308, 20 A.2d 30\%. (1941); Yarnall's Appeal, $70 \mathrm{~Pa}$. 335 (1872); Dodson v. Ball, $60 \mathrm{~Pa} .492$ (1869); Chase Trust, 7 Pa. D. \& C.2d 519 (Philadelphia Orphans' Ct. 1956). See also Horner Estate, 5 Fid. Rep. 648 (Philadelphia Orphans' Ct. 1955) and Reiniger's Estate, $36 \mathrm{~Pa}$. D. \& C. 163 (Berks County Orphans' Ct. 1939). But cf. Rech's Estate, 18 Pa. D. \& C. 466 (Philadelphia Orphans' Ct. 1933), where the court refused to terminate, holding the rule of Dodson v. Ball applicable only where the life tenant is the settlor. It failed to refer to Yarnall's Appeal, where the life tenant was not the settlor. If there is no gift over after a general power, some cases appear to conclude that the life tenant has a fee and can terminate. See Lyon v. Alexander, $304 \mathrm{~Pa}$. 288, 156 Atl. 84 (1931) ; Wood's Estate, $261 \mathrm{~Pa} .480,104$ Atl. 673 (1918); Miller Trust, 27 Pa. D. \& C. 239 (Philadelphia Orphans' Ct. 1962). In other cases, the courts have analyzed the facts to see who would take in default of exercise of the power. See Nelson v. Jackson, 354 Pa. 512, 47 A.2d 650 (1946) (intestacy, and life tenant was sole intestate heir); Jackson Trust, 351 Pa. 89, 40 A.2d 393 (1945) (reversion in settlor, who held the power); Ammon's Trust Estate, $52 \mathrm{~Pa}$. D. \& C. 509 (Berks County Orphans' Ct. 1944) (reversion in holder of power).

Where the gift in default of appointment is to the "issue" or "children" of the donee of the power, he does not have a fee. See Johnson v. Provident Trust Co., $280 \mathrm{~Pa}$ 255, 124 Atl. 436 (1924) ; Dodson v. Ball, supra; Rebmann Trust, 2 Fid. Rep. 288 (Philadelphia Orphans' Ct. 1952). See also McCreary Trust, 354 Pa. 347, 47 A.2d 235 (1946); Rickenbach Estate, 348 Pa. 121, 34 A.2d 527 (1943); Collins v. Provident Trust Co., 83 Pa. D. \& C. 459 (Montgomery County C.P. 1952). 
unborn persons, consent of all interested parties is impossible. In some cases where the "issue" are of a living person, for example the life tenant, termination has been decreed on a finding that it is impossible for that person to have issue. ${ }^{33}$ Here the courts have been quite liberal. Another possibility would be for the Court to appoint a guardian or trustee ad litem to represent minor and unborn beneficiaries, and to consent to termination in their behalf. There seems to be no authority concerning the power, or lack of power, of a guardian or trustee ad litem to give such consent. As a practical matter a guardian's consent will rarely be determinative since a court can, notwithstanding such consent, find that there is a material purpose for continuing the trust. The matter thus has significance only where the settlor is alive. In any event, in practice, guardians ad litem generally seem to oppose termination. ${ }^{34}$

Where a life tenant has the power to appoint the remainder, a gift in default of appointment to his issue, or to another class that includes minors or unborn persons, makes it impossible to obtain the consent of all beneficiaries. In such cases the life tenant may seek to utilize his power of appointment to cut off such interests. If, for instance, the power is exercisable by deed, he may at any time exercise it in favor of someone willing to consent to the termination of the trust. $^{35}$ Most powers, however, are testamentary only, and it should be clear that the donee of the power cannot make immediately effective, in advance of his death, a will exercising the power for the purpose of terminating the trust. ${ }^{36}$ Nor is it likely that the donee of a power

33 Bonham Estate, 393 Pa. 355, 143 A.2d 50 (1958) ; Kelby Estate, 80 Pa. D. \& C. 1 (Philadelphia County Orphans' Ct. 1961) ; Honeywell Estate, 70 Pa. D. \& C. 472 (Montgomery County Orphans' Ct. 1950); Leonard's Estate, $60 \mathrm{~Pa}$. D. \& C. 42 (Dauphin County Orphans' Ct. 1947) ; Barnsley Estate, 59 Pa. D. \& C. 653 (Montgomery County Orphans' Ct. 1947).

${ }^{34}$ See, e.g., Matthews Trust, 12 Fid. Rep. 653 (Philadelphia Orphans' Ct. 1962) ; White Estate, 25 Pa. D. \& C.2d 606 (Philadelphia Orphans' Ct. 1961); Close Estate, 83 Pa. D. \& C. 136 (Philadelphia Orphans' Ct. 1953). In Jones' Trust Estate, $284 \mathrm{~Pa}$ 90, 130 At1. 314 (1925), guardians for minor beneficiaries "submitted themselves to the judgment of the court," which denied termination because of the existence of contingent remainders in those beneficiaries. Id. at 92, 130 Atl. at 315 .

353 Scotr, Trusts $\$ 340$ (2d ed. 1956, Supp. 1965). Virtually the same result was accomplished in Goodell's Estate, $53 \mathrm{~Pa}$. D. \& C. 13 (Philadelphia Orphans' Ct. 1945), through the exercise by the settlor of a reserved power to modify the trust. He exercised it by naming his mother remainderman, and she then joined with him to terminate.

36 However, just this sort of thing has been tried, and in one case it was actually successful. In Reininger's Estate, $36 \mathrm{~Pa}$. D. \& C. 163 (Berks County Orphans' Ct. 1939), the income was payable to a daughter for life, with a general testamentary power in her to appoint the principal, which would pass to her heirs at law in default of appointment. The daughter executed a will, presumably exercising her power of appointment in favor of certain of her heirs who were joining with her in seeking to terminate the trust, and her petition included a request that her will be filed with the Register of Wills, so that she might not die intestate. The court stated that the purported will was ineffective, and could not be considered in any way in connection with determining whether all parties in interest had consented to the termination. 
could terminate a trust by contracting to make a will in which the power would be exercised in favor of persons who consent to the termination. ${ }^{\mathbf{3 7}}$

Recent cases, like Mattheres Trust, ${ }^{38}$ indicate that the courts will not participate in efforts of beneficiaries to cut off interests of

The parties were more successful in Elliot Estate, $88 \mathrm{~Pa}$. D. \& C. 528 (Lycoming County Orphans' Ct. 1953), where a will gave the residue of the estate in trust (no spendthrift clause) to pay the income to the testator's three children for life. On the death of the last surviving child, the principal was to pass under a general testamentary power of appointment in each child, who also had a power to appoint the income should he die before the termination of the trust. Gifts in default of appointment were given to each child's issue, or to the testator's grandchildren. Two of the three children, and their wives and children, petitioned to terminate their shares of the trust. Both testified that they had executed wills exercising the powers in favor of their wives or children, and took an oath that they would not change these wills. On the strength of this, the court terminated the trusts on the ground that everyone in interest had consented to the termination except the settlor, with respect to whom there was a "failure of purpose" because of the decrease in the amount of the income. Under the precept that a will is always revocable, it is hard to justify the conclusion that by an oath this testator lost the power to change his will, particularly in view of the possibility that his named legatees might predecease him. While a contract to make a will can, as a practical matter, limit testamentary freedom, it is difficult to fit this case into the pattern of such a contract; did, for instance, the beneficiaries named in the "irrevocable" will give consideration sufficient to prevent the testator from subsequently revoking it?

37 See Estate of Thomas Robb, No. 17, July Term, 1903 (Philadelphia Orphans' Ct., June 22, 1961), in which a unilateral "agreement" by the donee of a testamentary power to exercise it in favor of certain persons who joined in her petition to terminate, was held ineffective. See also Restatement, Property $\$ 340$ (1940), which bases its position on the view that the donor of the power intended that the donee retain until death the discretion to exercise it. The meager reported Pennsylvania authority appears to agree. See Hays' Estate, $286 \mathrm{~Pa}$. 520, 134 Atl. 402 (1925); Bailey's Estate, 276 Pa. 147, 151, 119 Atl. 907, 908-09 (1923), 287 Pa. 478, 135 Atl. 109 (1926), 291 Pa. 421, 140 At1. 145 (1927); Boyd v. Bigham, 4 Pa. 102 (1846); Trust Under Deed of Levering, $9 \mathrm{~Pa}$. D. \& C. 328, 330-31 (Philadelphia C.P. 1927). See also Scott's Estate, 353 Pa. 575, 46 A.2d 174 (1946); Duff's Estate, 7 Pa. D. \& C. 105 (Philadelphia Orphans' Ct. 1926).

This is to be contrasted to the donee's right to release a power, thus effectively passing the property to the takers in default of exercise. A general power may be released, Restatement, Property $\$ 334$ (1940)-even though this frustrates the donor's intent that the donee retain the discretion until his death-and one method to effectuate such a release is a contract with a taker in default not to exercise the power. Id. \$336; BREGY, op. cit. supra note 23 , at 5209. As a result of $\$ 3$ of the Estates Act of 1947 (and its prior statutory counterparts in 1943 and 1945) a special power of appointment may also be released, $i d$. at 5210 , although this is contrary to the Restatement, Properry \$335 (1940). Before the Act of 1943, P.L. 797 (predecessor to $\$ 3$ of the Estates Act), it seemed clear that a general power could be released in Pennsylvania. See Jackson Trust, 351 Pa. 89, 40 A.2d 393 (1945); Mogridge's Estate, 342 Pa. 308, 20 A.2d 307 (1941); Lyon v. Alexander, 304 Pa. 288,156 Atl. 84 (1931). The Lyon case indicated that this did not apply to a special power.

One problem has been that of spendthrift trusts. Before the Act of 1943, not only could a spendthrift interest not be transferred or released, it could not even be disclaimed or renounced at the outset. BREGY, op. cit. supra note 23 , at 5222-23. The Act of 1943 made clear that powers could be released, and the Act of 1945 extended this to interests including spendthrift interests. Id. at 5223. This was held inapplicable to pre-existing trusts. Borsch Estate, 362 Pa. 581, 67 A.2d 119 (1949); BREGY, op. cit. supra n.23, at 5224. The Estates Act of 1947, \$3(a), made the release of powers completely inapplicable to spendthrift interests, but in 1956 the Act was amended to restore the power to release a spendthrift interest, but only in favor of the descendants of the owner of the interest. Act of April 1, 1956, P.L. 1073.

3812 Fid. Rep. 653 (Philadelphia Orphans' Ct. 1962). 
parties who are unable to consent. That decision refused to interpret section 3 of the Estates Act of 1947 to permit a release of a life estate in favor of the remaindermen in order to terminate a trust. It is likely that an attempt to accomplish the same result through the release or exercise of a power of appointment will meet the same fate.

Matthews Trust also reveals that the courts will narrowly construe legislative efforts to change the rules. In narrowly interpreting section 3(a) of the Estates Act of 1947 to permit no termination at all, the court compared it to section 2(a), which grants the courts power to terminate trusts up to $\$ 25,000$, notwithstanding a spendthrift provision. $^{39}$ The latter, it said, is a true termination provision. Significantly, section 2 (a) reposes the power to terminate in the courts, and the courts have construed it liberally. ${ }^{40}$ In contrast, section 3 (a) gives rights to the trust beneficiaries, exercisable without court control or participation. The different interpretations of these two provisions, both intended to be remedial, emphasizes the courts' attitude that the continued existence or termination of trusts should be, so far as possible, a matter of court discretion and not of the "whimsy or caprice" of the beneficiaries.

The trend of the decisions involving termination by consent of the beneficiaries is toward increased court control. The "material purpose" of a trust that will override beneficiaries' attempts to terminate now appears to be found in almost every trust. By its very vagueness, that phrase has given the courts a broad discretion which the beneficiaries can neither limit nor influence, except in the area of inter vivos trusts where the settlor is still alive. The consent of all the beneficiaries is still essential, for without it a trust cannot technically be terminated by consent, regardless of the lack of a material purpose. But in view of the growing tendency of Pennsylvania courts to find a material purpose merely from the creation of a trust, and the difficulty of obtaining the consent of all interested parties, the consent of the beneficiaries is losing its significance as a ground for terminating trusts.

II

Termination for Failure of Purpose

Section 2(a) of the Estates Act of $1947^{41}$ permits the court, in its discretion, to terminate any trust, notwithstanding a spendthrift provision,

39 Pa. Stat. ANn. tit. 20, § 301.2(a) (Supp. 1967).

40 E.g., Ryan Trust, 11 Fid. Rep. 292 (Philadelphia Orphans' Ct.), aff'd sub nom. Ryan Estate, 404 Pa. 229, 127 A.2d, 584 (1961) (per curiam), holding a court may terminate a spendthrift trust under $\$ 2(a)$, even over the objection of parties beneficially interested.

41 Pa. Stat. AnN. tit. 20, §301.2(a) (Supp. 1967). 
provided the court after hearing is satisfied that the original purpose of the conveyor cannot be carried out or is impractical of fulfillment and that termination, partial termination, or allowance [from principal] more nearly approximates the intention of the conveyor ....

Notice is required "to all parties in interest." If the court finds a failure of purpose it may then distribute principal "as it deems proper and as nearly as possible in conformity with the conveyor's intention." 42 This provision is significantly limited, in that principal distributions thereunder may not exceed $\$ 25,000$ in the aggregate from all trusts created by the same conveyor. ${ }^{43}$

The statute has been principally utilized for the benefit of impecunious income beneficiaries of small trusts which contain no express power to invade principal for their benefit. The courts "are striking down, whenever possible, these so-called nuisance trusts where the corpus is so small that the benefits do not justify the trouble incident to their administration." 44 In most of the reported decisions granting termination, the corpus is small and the life tenant elderly, needy and a primary object of the creator's bounty. ${ }^{45}$ Inability of such a trust to support such a beneficiary is a "failure of purpose" under the statute. Where the facts do not fit this pattern, termination has generally been refused, ${ }^{46}$ and it is clear that the courts are so far interpreting "failure of purpose" narrowly.

The principal present significance of section 2(a) is that it allows termination of trusts, even though all interested parties do not join. It has been established that termination may be awarded under section 2(a) over the objection of one or more beneficiaries, ${ }^{47}$ provided they are given the notice the statute requires. ${ }^{48}$ More significantly, it clearly permits termination where the trust has created interests in minors or unascertained persons unable to give their consent. ${ }^{49}$

42 Pa. Stat. AnN. tit. 20, §201.2(b) (Supp. 1967).

43 P. Stat. AnN. tit. 20, \$301.2(a) (Supp. 1967).

44 Miller Trust, $27 \mathrm{~Pa}$. D. \& C. 239 (Philadelphia Orphans' Ct. 1962).

45 See ibid.; Ryan Trust, 11 Fid. Rep. 292 (Philadelphia Orphans' Ct.), aff'd sub nom. Ryan Estate, 404 Pa. 229, 127 A.2d 584 (1961) (per curiam) ; Merkel Trust, 3 Fid. Rep. 486 (Montgomery County Orphans' Ct. 1953).

46 Ballem Trust (No. 2), 12 Fid. Rep. 296 (Delaware County Orphans' Ct 1962) ; Curdy Trust, 2 Fid. Rep. 253 (Montgomery County Orphans' Ct. 1953). See Curry Appeal, $390 \mathrm{~Pa} .105,134$ A.2d 497 (1957), where the settlor created a spendthrift trust at the age of twenty-one, and sought to terminate it a few years later. The court found that the purpose not only had not failed, but was positively pressing in view of the settlor's dissipation of other funds.

47 Ryan Trust, 11 Fid. Rep. 292 (Philadelphia Orphans' Ct. 1961).

48 Curry Appeal, 390 Pa. 105, 134 A.2d 497 (1957).

49 See Comment of Joint State Govermment Commission, PA. Stat. ANN. tit. 20, $\S 301.2$ (a) (1950). 
Terminating trusts for "failure of purpose" antedated the Estates Act of 1947. A number of lower court decisions in Pennsylvania terminated small trusts for the benefit of a needy life tenant before the Act was passed. The first decision appears to have been Auchu's Estate. $^{50}$ That decision relied wholly on section 336 of the Restatement of Trusts, entitled "Termination in Case of Emergency," which permits termination by the court if, owing to circumstances not anticipated by the settlor, "continuance of the trust would defeat or substantially impair the accomplishment of the purposes of the trust." This was followed in Posey's Estate, ${ }^{51}$ and in subsequent lower court cases for which section 2(a) of the Estates Act was not available. ${ }^{52}$ The doctrine has not been reviewed (other than in cases decided under section 2(a) of the Estates Act) by any appellate court in Pennsylvania.

The reliance of these cases on section 336 of the Restatement is interesting, since that section is not only titled "emergency," but is illustrated with cases involving threatened loss of the trust property. ${ }^{53}$ It is a companion to section 335 , which allows termination if the purpose of a trust becomes "impossible," and refers principally to the destruction of the trust property. Neither section appears to contemplate the broad "failure of purpose" doctrine that the Pennsylvania cases have articulated, though the relationship is undeniable. ${ }^{54}$

These cases are not superseded by section $2(a),{ }^{55}$ which applies to principal payments only up to $\$ 25,000 .^{58}$ Beneficiaries seeking to terminate a larger trust for "failure of purpose" must rely on the prior case law. In doing so they must first determine whether ter-

$5038 \mathrm{~Pa}$. D. \& C. 33 (Cameron County Orphans' Ct. 1939).

$5152 \mathrm{~Pa}$. D. \& C. 127 (Montgomery County Orphans' Ct. 1944).

52 Exley Estate, $67 \mathrm{~Pa}$. D. \& C. 508 (Montgomery County Orphans' Ct. 1948) ; Holmes Estate, 66 Pa. D. \& C. 612 (Delaware County Orphans' Ct. 1940) ; Honeywell Estate, $70 \mathrm{~Pa}$. D. \& C. 472 (Montgomery County Orphans' Ct. 1950) ; Kelby Estate, 80 Pa. D. \& C. 1 (Philadelphia Orphans' Ct. 1952) ; Lamotte Estate, 84 Pa. D. \& C. 260 (York County Orphans' Ct. 1952) ; Hunsicker Trust, 2 Fid. Rep. 162 (Montgomery County Orphans' Ct. 1952) ; Bosler Trust, 3 Fid. Rep. 635 (Cumberland County Orphans' Ct. 1953), rev'd, 378 Pa. 333, 107 A.2d 443 (1954); Horst Estate, 86 Pa. D. \& C. 528 (Dauphin County Orphans' Ct. 1952) (alternative holding). See also Keller Estate, 80 Pa. D. \& C. 37 (York County Orphans' Ct. 1952).

53 To the same effect, see 3 Scotr, TRUsTs $\$ 336$ (2d ed. 1956).

54 The doctrine seems also to have derived something from the cases terminating trusts on consent where there is "no material purpose" for continuing them. See Bosler Trust, 3 Fid. Rep. 162 (Cumberland County Orphans' Ct. 1953); Kelby Estate, 80 Pa. D. \& C. 1 (Philadelphia Orphans' Ct. 1952).

Another parent, although the cases do not refer to it, may be the general rules allowing deviation from the terms of the trust, and more specifically the line of cases allowing a court to invade accumulated income, or even principal, for the benefit of a needy beneficiary who will eventually be entitled to it anyway. See 2 Scort, TRusts $\$ 168$ (2d ed. 1956).

55 Section 2(c) of the Estates Act of 1947 provides: "Nothing in this section shall limit any power of the court to terminate or reform a trust under existing law." Pa. Stat. AnN. tit. 20, §301.2(c) (Supp. 1967).

50 Pa. Stat. Ann. tit. 20, $\$ 301.2$ (a) (Supp. 1967). 
mination on this ground requires the consent of all the beneficiaries. In most of the cases, all of the beneficiaries did in fact consent, so the question was not reached. In at least two cases all of the beneficiaries did not consent, although none objected and the question was not discussed. ${ }^{57}$

The Commissioners' comment to section $2(a),{ }^{58}$ giving as a reason for the enactment of the section the difficulty of terminating small trusts because of the inability to obtain the consent of minor or unascertained beneficiaries, suggests that prior to the statute such consents were essential. This view is supported by analogy to the discussion in part I, supra. ${ }^{59}$

There is support for the contrary view. In Estate of Thomas $R o b b,{ }^{60}$ the guardian ad litem argued that the consent of all beneficiaries was necessary to terminate a trust for failure of purpose, just as it is for termination where there is no special or material purpose for continuing the trust. That case involved a $\$ 250,000$ trust to which section 2(a) of the Estates Act did not apply. Though it did not find a failure of purpose, the court disagreed with the guardian ad litem on this point and said:

In a substantial number of adjudications to which no exceptions have been taken this court has terminated trusts, even over objections, on the basis of inadequacy of income, although the principal sum involved was much larger than in [Auchu's Estate and Posey's Estate, where not all interested parties had consented]. The practice followed has been to permit the termination of a trust, whether spendthrift or not, when it was economically unsound to preserve the trust and the income was insufficient to achieve the testator's objective. $^{61}$

This view will probably be the one adopted. The cases preceding section 2(a) which first articulated the "failure of purpose" doctrine, were clearly working from general equitable principles, in an area where traditional property rules were freezing trust funds which could be better used for the primary beneficiaries. It offended ordinary concepts of justice that a life tenant, usually the wife or child of the testator, must subsist on inadequate income, while principal was preserved for a distant and unnamed class of remaindermen who

57 Posey's Estate, 52 Pa. D. \& C. 127 (Montgomery County Orphans' Ct. 1944); Auchu's Estate, 38 Pa. D. \& C. 33 (Cameron County Orphans' Ct. 1939).

58 See note 49 supra.

59 See text accompanying note 31 supra.

60 No. 17, July Term, 1903 (Philadelphia Orphans' Ct., June 22, 1961).

61 Ibid. 
could not legally consent to termination. Doubtless the "failure of purpose" doctrine derives a good deal from the cases that allow termination by consent of all beneficiaries if no "material purpose" is served in continuing the trust. The very words "failure of purpose" and "no material purpose" suggest a similarity. The two, however, are quite different, and in that difference lies the reason why the consent of all beneficaries should not be required to terminate for failure of purpose. The "no material purpose" cases are the traditional ones allowing termination upon the consent of all the beneficiaries. Such consent is the basis for termination. The "material purpose" is merely a qualification: termination will not be allowed, despite consent, if there is a material purpose in continuing the trust. Failure of purpose, on the other hand, is a different, almost converse, concept. It is a finding that the principal purpose for the creation of the trust can be better accomplished by terminating or modifying it. Logically, the consent or objection of one or more persons with beneficial interests should be irrelevant.

The doctrine is relatively new. It is equitable in nature and application, and depends wholly on the discretion of the court. To date the courts have been relatively restrained in the exercise of this discretion. ${ }^{62}$

\section{III}

\section{Termination for Mistake}

The rule allowing an instrument to be rescinded for mistake is developing into a new tool to assist beneficiaries seeking to terminate or modify a trust. ${ }^{63}$ The courts have always allowed the termination of a trust where it has been demonstrated that the settlor created it under a mistake. ${ }^{64}$ The mistake need not be "mutual" but may be

62 Almost all of the cases involved a needy income beneficiary. However, in Falkner Trust, 3 Fid. Rep. 495 (Philadelphia Orphans' Ct. 1953), Judge Saylor terminated a trust created to supplement a widow's income. The widow's income had never needed supplementing, and while the court found the case "not strictly one of 'failure of purpose" "it determined that it nevertheless came within that doctrine.

63 Like any instrument, a deed of trust may also be rescinded for fraud or undue influence, but in the great majority of cases where this has been tried, the effort has been unsuccessful. Quite obviously the pressure placed on a spendthrift, a weakminded person or a drunk to place his estate beyond his own reach is more approved than criticized. Trusts were terminated on these grounds in Miskey's Appeal, 107 Pa. 611 (1883) and Rick's Appeal, $105 \mathrm{~Pa} .528$ (1884). They were upheld in the face of charges of fraud or undue influence in King v. York Trust Co., $278 \mathrm{~Pa}$. 141, 122 Atl. 227 (1923) ; Brendle's Ex'r v. Brendle, 274 Pa. 590, 118 At1. 502 (1922); Willard v. Integrity Trust Co., $273 \mathrm{~Pa} .24,116$ Atl. 513 (1922); Potter v. Fidelity Ins. Trust \& Safe Deposit Co. (No. 1), 199 Pa. 360, 49 Atl. 85 (1901); Coleman's Estate, $193 \mathrm{~Pa}$. 605, 44 Atl. 1095 (1899); Neal v. Black, $177 \mathrm{~Pa}$. 83, 35 Atl. 561 (1896); Reidy v. Small, 154 Pa. 505, 26 Atl. 602 (1893) ; Merriman v. Munson, 134 Pa. 114, 19 Atl. 479 (1890).

64 Restatement (Second), Trusts \$333 (1959); 3 Scotrt, Trusts §333.4 (2d ed. 1956). 
solely on the part of the settlor where, as is usually the case, the creation of the trust is without consideration. ${ }^{65}$

Until recently most of the Pennsylvania cases have involved the omission of a power of revocation due to "mistake." Upon finding such a mistake, which is a question of fact, the courts have permitted the power to be exercised and the trust to be terminated. ${ }^{66}$ The courts' earlier readiness to find this kind of mistake may have stemmed in part from the general rule that a trust is irrevocable unless expressly made revocable. ${ }^{67}$

The courts no longer seem as ready to find a power of revocation omitted by mistake. In part this may be due to the increasing complexities of trusts, and to the fact that they are not entered into, as a general rule, without intelligent consideration and legal advice. ${ }^{68}$ Where, for instance, a trust must be irrevocable for tax reasons, a court is unlikely to accept the argument that a power of revocation was omitted by "mistake." 69

In any event, the courts are taking a more sophisticated approach. On the one hand, they are making only such changes in the terms of the trust as the circumstances require, without affecting the continuation of the trust. In Irish $v$. Irish, ${ }^{70}$ the reformation consisted only of inserting a provision for an omitted contingency-the settlor's survival of all the named beneficiaries. In Sartelle Trust, ${ }^{71}$ reforma-

653 ScoTt, TRUSTS $\$ 334$ (2d ed. 1956).

66 Bristol v. Tasker, $135 \mathrm{~Pa} .110,19$ Atl. 851 (1890) (settlor allowed to terminate on a finding her mother told her she could revoke so long as she was single) ; Russell's Appeal, $75 \mathrm{~Pa} .269$ (1874) (settlor of sole and separate use trust failed to include power to revoke if she should survive her husband). See also Armstrong v. Germantown Trust Co., $12 \mathrm{~Pa}$. D. \& C. 519 (Philadelphia C.P. 1929) ; Hood v. Leach, $29 \mathrm{~Pa}$. Dist. 517 (Philadelphia C.P. 1920) ; Geiger's Estate, 3 Pa. County Ct. 338 (Philadelphia Orphans' Ct. 1887) ; Hickman v. McFarland, 1 Pa. County Ct. 195 (Chester C.P. 1886).

67 Donnan's Trust Estate, $339 \mathrm{~Pa} .43,13$ A.2d 55 (1940); Wilson v. Anderson, $186 \mathrm{~Pa}$. 531, 40 Atl. 1096 (1898).

68 In Curry Appeal, $390 \mathrm{~Pa}$. 105, 134 A.2d 497 (1957), the settlor of a trust created at 21 , when seeking to terminate it only a few years later, alleged a mistaken omission of a power to revoke (as well as a host of other grounds). The court found him an intelligent person who knew what he was doing. In Irish v. Irish, $361 \mathrm{~Pa}$. 410, 65 A.2d 345 (1949), a decision of the court below dismissing a petition for reformation was reversed, and the case remanded to determine if an alleged omission was due to the inadvertence of the scrivener or not. The deed had failed to provide for the disposition of the property in the event the settlor survived all the named beneficiaries. The reversion that would occur created unexpected tax consequences to the settlor, as a result of a United States Supreme Court decision. Estate of Spiegel v. Commissioner, 335 U.S. 701 (1949).

69 In Fisher Trust, 12 Fid. Rep. 313 (Philadelphia Orphans' Ct. 1962), one of the purposes of the trust was to remove the assets from settlor's estate for tax reasons, and the trust was expressly made irrevocable for that reason. Reformation of the terms obviously could not be had by inserting an omitted power to revoke.

70361 Pa. 410, 65 A.2d 345 (1949).

7112 Fid. Rep. 665 (Philadelphia Orphans' Ct. 1962). 
tion was granted to include as "issue" the adopted children of one of the settlors. By the same token, the courts are giving short shrift to beneficiaries asserting "mistake" among the grounds for seeking a complete termination of the trust. ${ }^{72}$

On the other hand, the courts seem to be taking a somewhat broader approach to the question of what is a mistake. This is suggested by Sarutelle Trust. ${ }^{73}$ Since the trust was created in 1935 and since it was not until 1940 that one of the settlors discovered she could not have children, a traditional interpretation of "mistake" might not have been adequate for reformation. In any event, the court found that the settlors were young when, at their parents' request, they created the trust; that they had not had an opportunity to discuss the terms of the trust with the parents' attorney; and that there had been no discussion of what "issue" meant. Stress was placed on the fact that all the settlors agreed to the proposed change, and that to allow it would be to approve a "family agreement."

A broad approach was also taken in Fisher Trust, ${ }^{74}$ where a settlor had created three irrevocable trusts for the benefit of his children. $\mathrm{He}$ and his wife were not beneficiaries of the trusts because of what he believed to be adequate provision for them under certain employment contracts. On later changing lawyers, the settlor learned that (i) since the employment contracts were probably unenforceable, the expected income to himself and his wife could not be guaranteed, and (ii) though the trusts were aimed at removing the trust property from settlor's estate for tax purposes, the reservation by him of a power to invade principal for the beneficiaries would place the trust in his estate. The court allowed reformation on the ground that the exclusion of the wife from the trusts, and the inclusion of the taxable power, were "mistakes" justifying reformation. Stress was placed on the fact that settlor was blind and thus less able than most to "comprehend the complexities of the testamentary plan he created." 75 But while the court based its conclusion on "mistake," it described the proceeding as a request to the court "for permission to revise a trust in which all of [settlor's] assets are tied up in an impractical, unworkable and economically unsound plan." 76

72 E.g., Curry Appeal, 390 Pa. 105, 134 A.2d 497 (1957).

7312 Fid. Rep. 665 (Philadelphia Orphans' Ct. 1962).

7412 Fid. Rep. 313 (Philadelphia Orphans' Ct. 1962).

75 Id. at 323 .

$76 I d$. at 324. The opinion does not specify just what reformation was ordered. Nothing is said, for instance, as to efforts, if any, to amend the employment contracts. Nor is it clear whether the deed was to be reformed to make only the wife, or both she and settlor, income beneficiaries. If he was to be included, the trust would seem to be taxable to his estate under INT. REv. CoDE of 1954, \$2036. 
Kaufman Trust ${ }^{77}$ evidences an even broader view and suggests that a trust may be reformed, not merely for mistake in the traditional sense, but also where, because of lack of foresight or poor judgment, the settlor has put himself in a difficult position. There the settlor petitioned to terminate an irrevocable trust of substantial size created ten years before, in which he had reserved the income for life and given the remainder to his brothers or their issue. Subsequently his fortunes changed radically. The family company which had paid him an annual salary in excess of $\$ 35,000$ a year was sold, his investments went sour, his health failed and he got married. $\mathrm{He}$ sought termination on the ground of mistake, claiming that while he realized the trust was irrevocable, he and his brothers thought that meant only that settlor could not revoke by himself, but could revoke if the brothers agreed (which they did). The court found "a mistake of fact and law" sufficient to terminate, but in view of settlor's prior unsuccessful speculations, ordered periodic payments of principal to him or for his benefit instead of terminating the trust.

The only "mistake" in the traditional sense suggested by the petitioner in this case was his belief that he and his brothers, the named remaindermen, could terminate the trust by consent. Like an omitted power of revocation, this would have resulted in the complete termination of the trust, which the court expressly refused to decree because of settlor's proven speculative habits. Instead the court awarded a "partial termination" to permit settlor to pay certain debts and receive a monthly income. Though the basis for the decree was stated to be a mistake as to the power to terminate, it seems clear that the court was in fact relieving settlor from an improvident scheme into which it concluded he should not have entered. It expressly relied not merely on the "mistake,"

but also the principles of law which dictate that we approach the general problem of giving relief to a person who voluntarily places his oren money in trust in a benign spirit, so that in the end he should not be regarded as a stranger in the realm of his own benevolence. ${ }^{78}$

These cases show a broader reference to general equitable principles than the early mistake cases, ${ }^{79}$ and suggest a similarity to the development of the "failure of purpose" cases (part II, supra). In Kanfman Trust, the similarity of termination for "mistake" and ter-

7712 Fid. Rep. 550 (Philadelphia Orphans' Ct. 1962).

78 Id. at 555 .

79 In Sawtelle Trust, 12 Fid. Rep. 665 (Philadelphia Orphans' Ct. 1962), the court emphasized its power to wield all the powers of a court of equity. Id. at 668 . See also Fisher Trust, 12 Fid. Rep. 313, 314-15 (Philadelphia Orphans' Ct. 1962). 
mination for "failure of purpose" is apparent, for what the court did was to approve the invasion of principal, in a case in which it expressly found section 2(a) of the Estates Act to be inadequate because of its $\$ 25,000$ limitation. Here, as in the failure of purpose cases, the rights of other beneficiaries and the necessity of their consent may create problems. Logically the consent of the beneficiaries should be unnecessary. In each of the above three Philadelphia Orphans' Court cases, ${ }^{80}$ the attitudes and rights of all beneficiaries were considered material, ${ }^{\text {sI }}$ but it should not be deduced from this that a prerequisite to reformation or termination for mistake is the consent of all the beneficiaries. Rather it indicates that the courts will weigh the rights of parties interested in the trust as an important factor in determining what equity dictates in a given case. That this factor is to be given special weight is indicated by the uniform appointment of guardians ad litem. ${ }^{82}$ It is significant that in the only recent cases refusing relief on the ground of mistake, the petition was opposed by another party. ${ }^{83}$

The broad view of mistake has been questioned by the most recent decision of the Supreme Court. In LaRocca Trust, ${ }^{84}$ the court reversed a decree of the lower court which had reformed a trust to make the settlor one of the beneficiaries. ${ }^{85}$ The reasons given suggest that reformation or termination for mistake may still be viewed narrowly. The court insisted that evidence of mistake must be "clear, precise,

80 See also Boies Trust, 15 Fid. Rep. 310 (Lackawanna County Orphans' Ct. 1965 ), where the court permitted the reformation of a partial release of a power of appointment where it found releasor had made a "mistake" about the tax consequences of the release.

81 In Sawtelle Trust, 12 Fid. Rep. 665 (Philadelphia Orphans' Ct. 1962), the first of the "special circumstances" listed by the court in favor of its conclusion was that " $[t]$ he original owners of the trust res are whole-heartedly and unanimously in favor of the amendment." 12 Fid. Rep. at 670. In Fisher Trust, 12 Fid. Rep. 313 (Philadelphia Orphans' Ct. 1962), the court described as "one of the most important features of these proceedings. . the effect of reformation upon the rights of minors and possible unascertained interests," emphasized that a guardian ad litem representing such interests had approved the reformation, and stressed that reformation would be a greater long range benefit to such interests than what might be initially lost by diminishing their interests in the trust. In Kaufman Trust, 12 Fid. Rep. 550 (Philadelphia Orphans' Ct. 1962), a guardian ad litem was appointed and agreed to the awards there made.

82 See notes 8, 34, 81 and text accompanying note 34 sipra.

${ }^{83}$ LaRocca Trust, $441 \mathrm{~Pa}$. 633, 192 A.2d 409 (1963), reversing a decree of the Orphans' Court of Montgomery County, 12 Fid. Rep. 671, which reformed a deed to make the settlor an income beneficiary. The settlor's grandson, who had been named the income beneficiary, objected and appealed. See also Curry Appeal, $390 \mathrm{~Pa}$. 105, 134 A.2d 497 (1959), where the trustee opposed termination successfully, and Cobaugh Trust, 16 Fid. Rep. 377 (Philadelphia Orphans' Ct. 1966), where the settlor's request to terminate was opposed by several parties, and was denied by the court which found no "mistake," but merely a change of heart by the settlor, who did not get along with the trustees.

84 $411 \mathrm{~Pa} .633,192$ A.2d 409 (1963).

85 For the subsequent history of this case, see LaRocca Trust, $419 \mathrm{~Pa} .176,213$ A.2d 666 (1965). 
convincing and of the most satisfactory character," 86 a phrase rather often used by the Supreme Court in trusts and estates cases when it decides against the proponent of the evidence, and an idea not hitherto expressed in a case involving termination or reformation of a trust. Significantly, the court said, "any other rule would do havoc to the status of many irrevocable trusts now in existence," and it briefly distinguished prior cases as ones where the reformation did not "substantially eliminate any operative provision of the trust instruments." 87 These statements, which suggest that an irrevocable trust will not be modified unless it can be proven by clear evidence that a particular mistake in its drafting was made, are not in accord with the broad equitable principles which the lower courts have been developing. It may be that LaRocca Trust was not a proper case for the application of those principles, since it is not clear that the settlor was in financial straits or had created an impractical or improvident scheme. On the other hand the lower court had applied those principles, and the Supreme Court's reversal reads as a repudiation of the principles as much as a refusal to apply them. ${ }^{88}$

A broad view of "reforming" a document for "mistake" could lead to a re-writing of the dispositive provisions of a trust to accord with what the settlor probably intended, even though his words say something else. Duncan Trust, ${ }^{89}$ suggests such a possibility. There the court "reformed" an inter vivos trust deed, after the death of the settlor, solely on the testimony of the scrivener that he had made a mistake in the preparation of the last amendment of the deed. The effect of the language of that amendment was to give the remainder to some, but not all, of settlor's grandchildren, a result which everyone agreed was surely not intended. Plainly influenced by the particular facts, ${ }^{90}$ the court was eager to reform the instrument, and did so by

$86411 \mathrm{~Pa}$. at $640,192 \mathrm{~A} .2 \mathrm{~d}$ at 412.

87 Ibid.

88 The only other recent supreme court decision on mistake is Scholler Trust, $403 \mathrm{~Pa} .97,169$ A.2d 554 (1961), which is a curious and in some ways confusing decision. In that case, alleged heirs of the creator of a charitable foundation, formed by an irrevocable trust instrument, attacked its validity charging that certain purposes stated in the instrument were not charitable. The court held the trust a valid charitable one, but added that the questioned purpose had been effectively removed by two amendments to the trust executed by the settlor before his death. In view of the fact that the trust was irrevocable and unamendable, the court stated that these "amendments" amounted to a "reformation" of the trust to cure a "mistake." No other case has ever suggested that reformation is something that can be accomplished by the settlor out of court.

8916 Fid. Rep. 189 (Washington County Orphans' Ct. 1965).

90 Settlor was 90 when she executed the amendment, which had been prepared for her by an officer of the trustee bank who was also a lawyer, but who did not in fact see settlor execute the amendment and did not even consult her about it. $\mathrm{He}$ also testified that it was his secretary who made the mistake by including a clause which should have been omitted. 
resort to the old English practice of striking out words found to be included by mistake. One wonders if the court could have reached the same result if the instrument had been a will, since it had been duly executed and was in no way ambiguous or unclear.

\section{CONCLUSION}

Trusts are a fit subject for the application of flexible equitable principles. In perhaps no other field is there so great a possibility that unforeseen changes in circumstances will frustrate a purpose which led to the fixing of unchangeable property rights years, or even generations earlier. In general, the lower courts in Pennsylvania are treating problems of termination or reformation of trusts with a greater regard for general equitable principles than for traditional rules of property. When tempered by due regard for the rights of all the beneficiaries, as is so far the case, this is a healthy, realistic and just approach. Currently the greater presence of the conscience of the court is working both ways. On the one hand, it is allowing changes in trusts for the benefit of the principal beneficiaries, both through the failure of purpose doctrine and the principle of mistake. On the other hand, it is narrowing the right of beneficiaries to terminate a trust by consent through the broadening of the concept of the "material purpose" which prevents beneficiaries from doing so.

Possibly there runs through these developments a hint of paternalism, the idea that the court knows best whether a trust should continue or not, and on what terms. If so, it may be a by-product of rules which by their nature leave much to the courts' discretion. To date the decisions have certainly given due regard to the intention of the creator of the trust and the interests he has given to his beneficiaries. What the recent decisions are recognizing is that it is often unjust, and sometimes absurd, to honor slavishly the specific intention of the creator of a trust after the passage of years and the development of circumstances which he did not, and in many respects could not, envisage. The recent decisions are sacrificing specific intent to a general or underlying intent which can usually only barely be discerned from the trust instrument, and which the courts must find primarily in their own knowledge of human experience. Indeed for a court to look only to "specific intent" in the face of facts which the settlor did not foresee, suggests either a blind spot or an unwillingness to dig into the heart of the problem. 